Historic, Archive Document

Do not assume content reflects current scientific knowledge, policies, or practices. 


\title{
Midsummer List
}

\author{
of
}

CHOICE FLOWER SEEDS

STRAWBERRY PLANTS

PEONY ROOTS

I R I S ES

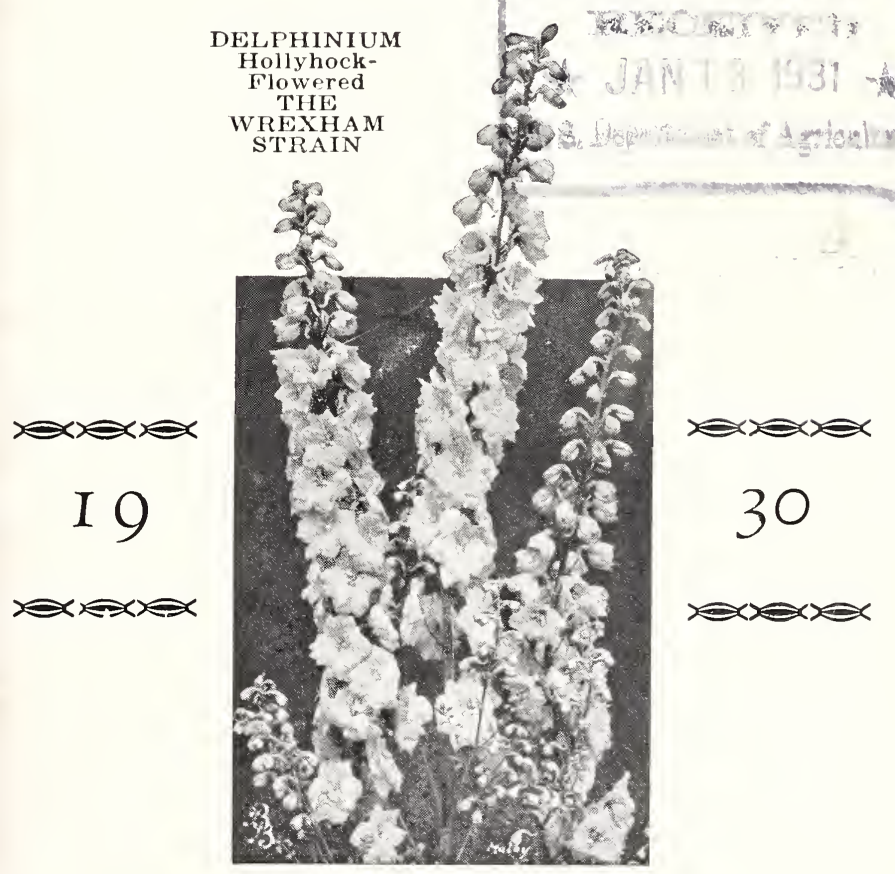

\section{BURNETT BROTHERS, Inc,}

Seedsmen

92 CHAMBERS ST.

NEW YORK 


\title{
BURNETT'S SELECTED FLOWER SEEDS
}

\author{
For Summer Sowing
}

\section{BURNETT'S GIANT PANSIES SELECTED STRAINS}

SCOTTISH CrIfFTAIN. This magnificent strain of Pansies is the mosi remarkable in existence not only in size, but in the wonderful variety of rich and brilliant coloring. ....1/4 oz. $\$ 4.00,1 / 8$ oz. $\$ 2.50$, Burnett's Gorgeous. This select strain contains a most beautiful collection of colors and markings.

Mrasterpiece (Frilled T'ansy). Petals beautifully waved. Mixed colors.................... oz. $\$ 2.00$

IIme. Perret. Profuse bloomer, many tine colors, rich red shades $1 / 4$ oz. $\$ 2.00$

Triumph of the Giants. Flowers extremely large, with beautiful markings. Mixed colors.

Orange king. The lower portion of the flower is of a vivid orange color, shading at the center to a lighter tone $1 / 4$ oz. $\$ 2.50$

Ullswater. (New.) The flowers are very large and the coloring unusually attractive, being deep wedgewood hlue with hlack-blue center

Burnett's Special Greenhouse Irixture.

\section{FANSIES IN SEPARATE COLORS}

Adonis. Light blue

Azure Blue. Sky-blue

Bronze Queen. Rich bronze.

Emperor. Ultramarine blue

Fire King. Crimson and gold

Giant Snow Queen. Pure white.

Giant White. White with purple eve

Golden Queen. Pure yellow

Giant Golden. Yellow, with dark eve

Giant Striped. Mahogany, striped whit

King of the Blacks. Glossy black

Iord Beaconsfield. Purple violet

Royal Purple. Rich royal blue

Victoria. Wine-red

Burnett's Giant Mixture

$\begin{array}{rrr} & \text { 1/1. oz. } & \text { Pkt. } \\ \$ 1.50 & \$ 0.15 \\ 1.50 & .15 \\ 1.50 & .15 \\ 1.50 & .15 \\ 1.50 & .15 \\ 1.50 & .15 \\ & 1.50 & .15 \\ & 1.50 & .15 \\ & 1.50 & .15 \\ \text { ite } & 1.50 & .15 \\ & 1.50 & .15 \\ & 1.50 & .15 \\ & 1.50 & .15 \\ \text { Oz. } \$ 3.00,1.00 & 1.50 & .15 \\ & 1.50 & .15 \\ & & .10\end{array}$

\section{Giant Winter Blooming Pansies}

These Pansies begin flowering early in March and continue right on into Summer. The flowers have a pleasant delicate perfume.

Celestial Queen. Sky-blue

Ice King. White with dark bloteh

March Beauty. Dark velvety purple

winter sun. Golden yellow, dark blotch

Mirsed

$\begin{array}{rr}14.0 z . & \text { Pkt. } \\ \$ 1.50 & \$ 0.25 \\ 1.50 & .25 \\ 1.50 & .25 \\ 1.50 & .25 \\ 1.50 & .25\end{array}$

\section{ANTIRRHINUM}

\section{Greenhouse Forcing Varieties}

Seeds saved from selected spikes grown under glass.

CEYLON COURT YEILOW. (New.) A beautiful canary yellow, $40-4 \delta$ inches high, spikes $10-14$ inches, with flowers closely set. One of the earlies 1

Pkt.

GENEVA PINK, Color, a delightful glistening rosepink, long spikes.

GOIDEN DEIIGHT. Very fine golden yeliow

JENNIE SCHNEIDER. Beautiful pink Columbia rose color 


\section{SELECTED FLOWER SEEDS}

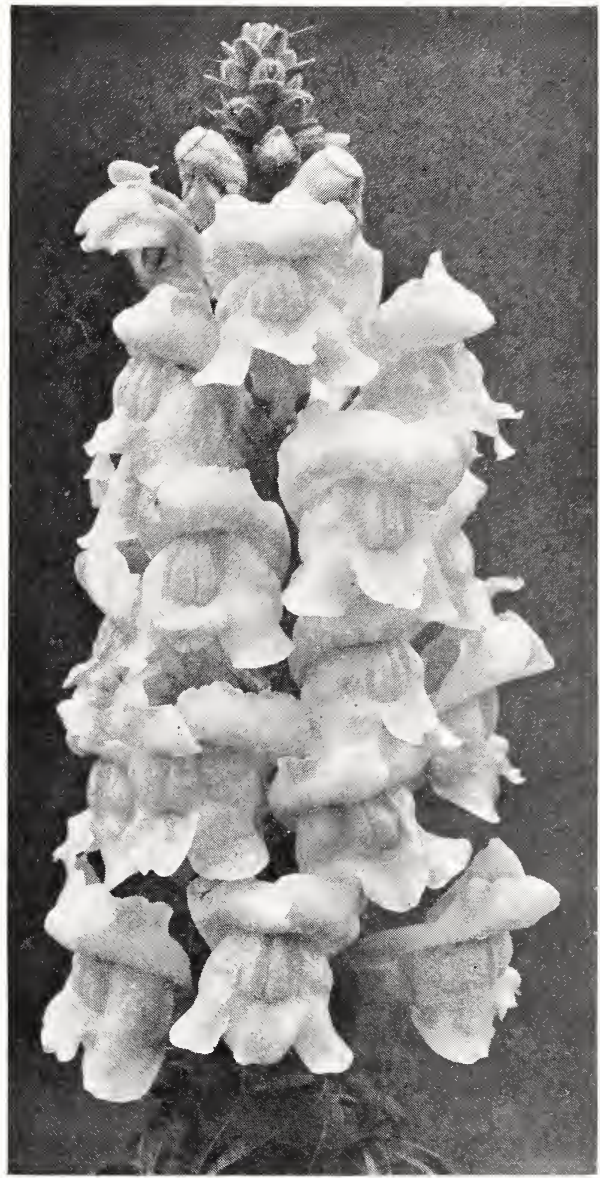

ANTIRRIINUIM-Continueã

LAURA. Glossy, deep rose-pink. Medium height, heavy flower head, averaging eleven inches.... 2.00 ORLANDO. Lovely bronze ................ PENN-ORANGE. A vivid orange. Upright and vigorous growth

PHILADEIPHIA PINK. Popular pink

WHITE ROCK. Extra early, undoubtedly the best white

(Any variety not listed will be procured to order at advertised prices.)

ASPARAGUS, Plumosus Nanus $\quad 100$ seeds $\$ 1.00$ Sprengeri. A graceful drooping variety.

BLUE LACE FLOWER (Didiscus) $\quad 100$ seeds $50 \mathrm{c}$ BROWAILIA Speciosa Major. Clear blue

viscosa. Bright violet blue.

CaICEOIARIA, Burnett's superb strain, Choice mixed Albert Kent. Bright golden yellow with maroon blotch

Albert Kent Hybrids. Many vivid colorings

Clibrani. Of shrubby habit, strong and vigorous in growth, abundance of beautiful lemon-yellow flowers 


\section{SELECTED FLOWER SEEDS}

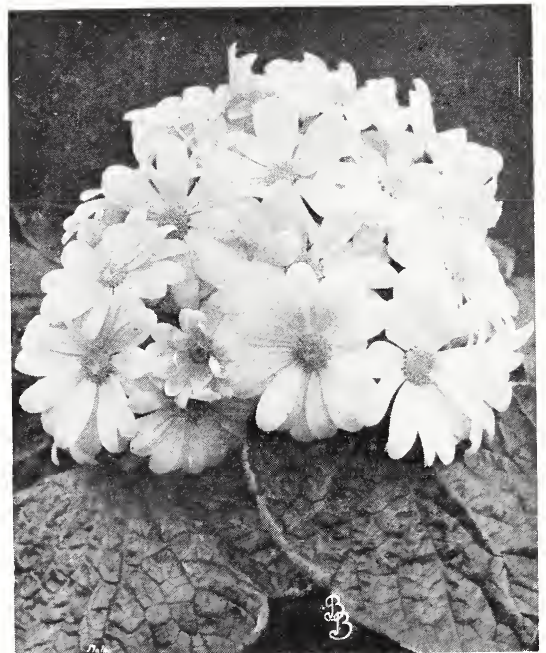

Cineraria; Burnett's Exhibition

Calendula, The Ball. Bright glowing orange, excellent for forcing

$1 / 4$ oz. $\$ 1.00$

Monarch. of great size. Color purest orange.

\section{Iemon Queen}

Orange King. Improved

$1 / 4$ oz. $\$ 1.00$ 1 . Oz. $50 \mathrm{c}$

Raclio. (New.) The petals are beautifully quilled of a deep orange color, quite distinct variety.

Sensation (Campfire). Of vigorous growth. Flowers larger than those of any type previously introduced

$1 / 4$ oz. $\$ 1.25$

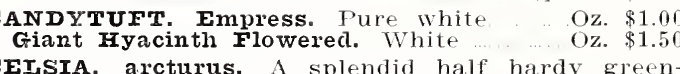

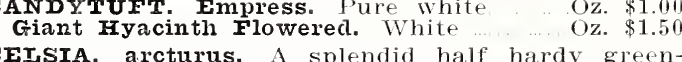

CEISIA. arcturus. A splendid half hardy green-
house plant with long spikes of bright yellow fiowers

cretica. A beautiful plant producing numerous large yellow flowers on long stems

Centaurea. Cyanus. (Cornfiower). Double blue.

Imperialis. (Giant sweet Sultan.) Rose, white lilac, each (Giant sweet sultan.) Rose, white, suaveoleus, Yellow sweet sultan. Fine for cutting.

Chrysanthemuin. (Single Annual.)

Evening Star. Golden yellow

Morning Star. Primrose

Northern star. Pure white

Single IMixed

$1 / 4$ oz. $50 \mathrm{C}$

$1 / 4$ oz. $30 \mathrm{C}$

$1 / 4$ oz. $30 \mathrm{C}$

$1 / 4$ oz. $30 \mathrm{C}$

$1 / 4$ oz. $25 \mathrm{c}$

\section{CINERARIA}

BURNETT'S EXHIBITION STRAIN. Our strain of this highly prized greenhouse plant we can recommend as being superior to any other.

inixed colors

Hybricla IVatador. Brilliant coppery-scarlet

Hybricla Rosamond. A true delicate pink with white center

Hybricla, Giant Dark Blue

Hybrida "Purple IMantle." A real purple of compact habit

IXybricla IVIultiflora Nana. Produces masses of small flowers on compact heads. Mixed colors

Steurata. Star flowered. Pink, Blue, white. Mixed Each

Feltham Beauty. A great improvement on the old stellata class. Beautiful mixture of many colors stellata nama. Cactus flowered, mixed 
CIERODENDRON Fallax. Large spikes of fiery scarlet bloom.

CIARIIA elegans fl. pl.

\section{Salmon}

Scarlet

Rose Carmine

$1 / 4$ oz. $50 \mathrm{c}$

CYCIAMEN. BURNETT'S GIANT STRAIN. Pure White, Rose, Pink, Salmon, Crimson, Bright Red, White with Claret base Each 100 seeds, $\$ 2.50$ Choice IVlixed 100 seeds, $\$ 1.50$ persicum papilio (Butterfly). Flower's beautifully fringed. Mixed

CynoGIossum Amabile (Chinese Forget-Me-Not). Produces sprays of blue Forget-me-not like Howers. 18 in.

DIDIscus coeruleus. ('The Blue Lace Flower.)

DIMORPHOTHECA (African Daisies).

aurantiaca. H. A. Gorgeous orange flowers, produced in great profusion. $12 \mathrm{in.} \quad 1 / 4 \mathrm{oz} .50 \mathrm{c}$.

New Selected Hybrids. Produces an endless variety of colors. …... . 1/4 oz. $75 \mathrm{c}$

Eklonis. Pure white star-shaped flower's with blue dise on long stalks

DRACAENA. Highly ornamental greenhouse plants, Australis. Ornamental leaves....... 1. $14.35 \mathrm{c}$

Indivisa. Long, slender leaves..... $1 / 4 \mathrm{oz} .35 \mathrm{c}$

veitchii. Variegated leaves.

EXACUIM affine. Beautiful pot plant, producing sweetly scented bright mauve flowers, within six months from sowing. 9 in.

\section{GERBERA}

GERBERA Jamesoni Hybrida. These new hybrids are of great merit and contain a grand diversity of colol's

Jamesoni. Orange-scarlet......... 100 seeds $\$ 1.00$

GIoxrma. Charming greenhouse plant. Erect flowering. Mixed

GREVIILEA Robusta (Silk Oak). A beautiful decorative plant........ $75 \mathrm{c}$

\section{GYPSOPHIIA.}

Elegans grandiflora alba. Large, pure white flowers srandiflor. $60 \mathrm{c}$

Rosea. Rose flowers

LARKSPUR. (Annual Delphinium.)

Doukle Stock Flowered:

Pure White, Sky Blue, Shell-Pink, Bright Rose, Dark Blue, Scarlet, Mixed Each, $1 / 4 \mathrm{oz} .50 \mathrm{c}$ Exquisite Pink Improved. Beautiful soft pink shaded salmon $\quad \ldots 1 / 4$ oz. $\$ 1.00$ Newport Pink. Color rosy-scarlet......1/4 oz. $50 \mathrm{C}$
Blue Butterfly. Bright blue........ $\$ 1.00$ Blue Butterfly. Bright blue........1/4 oz. $\$ 1.00$ IEPTOSYNE Stillmannii, bright yellow, free flowermaritima. Large-flowered yellow Marguerite, fine for cutting............................................... $50 \mathrm{c}$ 
IUPINUS (Annual varieties).

Hartwegii. Iight Blue ……....1/4 oz. $25 \mathrm{c}$ Dark Blue, very fine.................1/4 oz. $25 \mathrm{c}$

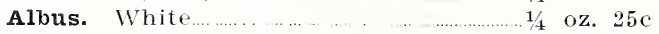

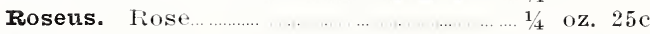
IMixed

oz. $50 \mathrm{c}$

Iuteus. Yellow Annual Lupine........... 1/4 oz. $50 \mathrm{c}$

IVIGNONETTE. Burnett's Conqueror. The finest Mignonette ever introduced for gleenhouse grow-

ing

Myosoris, Burnett's winter Blooming. Large flower, dark blue, reconmended for Winter bloom

NEMESIA Strumosa Suttoni. Choice mixed

compacta, Blue Gem. Beautiful Forget-me-not blue White Grem

Fire King. Carmine scarlet

Orange Prince. Golden yellow

\section{PRIMULA}

Sinensis Fimbriata (Chinese Primula). Single large Howered, fringed.

White, Pink, Crimson, Salmon, Blue _.......Each

Single IMixed. Choicest colors

Double Mixed

Stellata (Star I'rimiose).

Giant White Star. Pkt.

Giant Pink Star

obconica Gigantea.

Giant White

Giant Iilac

Giant Crimson

Giant Salmon

IVIalacoicles.

Any of the above, 75c Pkt.

Lilac. Light lilac

Rosea. Light rose

Superba. Deep rosy pink

Fimbriata. Lovely pink, delicately frunged

Pink Beauty. Beautiful rosy pink

Courtland's Seedling. Clear lilac pink, very brilliant

Snow Queen. Is a vast improvement on the Primula Malacoides Alba hitherto grown, Hower's larger and of the purest white

Choice Mixed

.75

Kewensis. Bright yellow fragrant flowers produced in whorls. Fine for Winter bloom

Forbesii (Baby Primrose). Small lavendercolored flowers

SAIPIGLOSSIS, Large-Flowering or Emperor.

Iight Blue, Crimson, White, Dark Rec, Rose, Yellow, violet. Each

Finest Mixed

$1 / 4$ oz. $75 \mathrm{C}$

SCIIZANTHUS.

Wisetonensis "Excelsior." An improved Wisetonensis. The flowers have white, buff or rose grounds. $\quad 1 / 16$ oz. $\$ 1.50$

Pink Pearl. Of elegant pyramidal habit, producing a luxuriant wealth of bloom

Snowflake. Very compact habit, with a profusion of glistening snowy-white flowers

Dr. Badger's Hybricls. Flowers of great substance, produced in large quantities.

Garraway's Fybricls. Of fine form and great range of colors

Furst's IMonarch Strain. One of the finest strains of large-flowered hybrids, embracing a wide range of colors

Rose and Amber Shades. Pink and rose tints, most heavily blotched gold and bronze

STATrCE suworowii. Beautiful soft rose $1 / 4 \mathrm{oz} .75 \mathrm{c}$ 


\section{SELECTED FLOWER SEEDS}

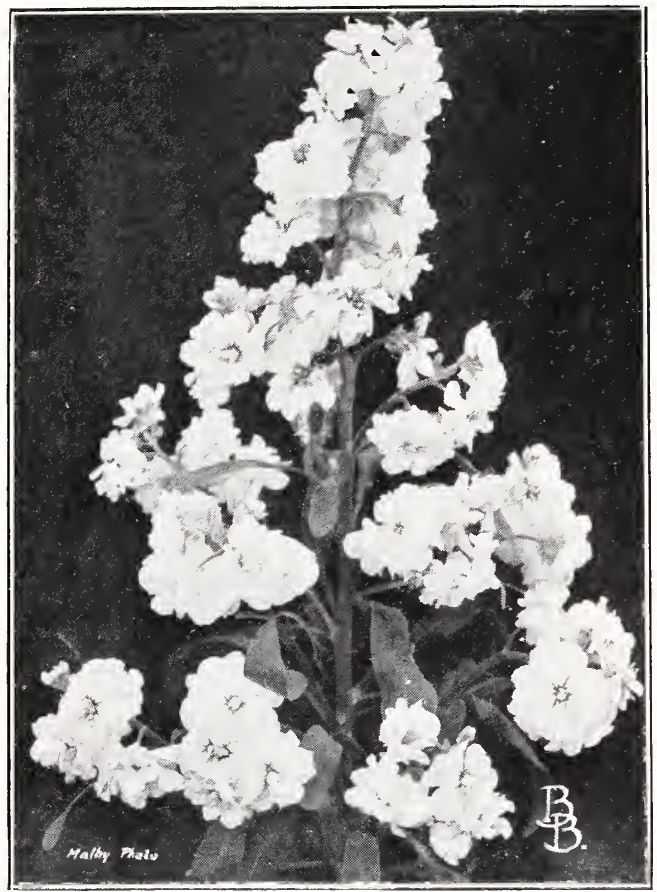

Stock, Burnetl's Perpetual White

\section{STOCKS}

\section{WINTER-FTOWERING OR BEAUTY}

Burnett's Perpetual white. For forcing purposes this stock is unrivaled

Beauty of Nice. Delicate pink

Crimson King. Rich crimson

Fmpress Augusta Victoria Rich hlut

Empress Elizabeth. Deep rose 1.25

Mont Blanc. Purest white … ...

Queen Alexandra. Fine lilac … 1.25

Salmon King. Bright salmon rose 1.50

Soleil de rice. Purest sulphur yellow $\quad 1.25$

Summer Night. Deep blue. ... ... 1.25

EARIY GIANT IMPERIAX (Improved Bismarck).

An especially meritorious class. Growing from twenty-four to thirty inches tall; of branching habit. Very early blooming and producing a high percentage of doubles.

"Antique Copper." Rich Helebore red

"Elk's Pricle." Intense roval purple.

"Golden Rose." Light golden rose

STREPTOCARPUS. Giant Hybrids. Mixed

TECoIMA SIMITHII. Beautiful autumn and early winter flowering plant, with large heads of orange-colored tubular-shaped blossoms. 18 inches.

$\$ 0.25$

TORENIA. For pots or hanging baskets.

Fournieri. Blue and violet, throat bright yellow.

\begin{tabular}{l}
$1 / 16$ oz. 75 \\
\hline
\end{tabular}

Bailloni. Golden yellow, red throat
WAIIFIOWER. Kewensis-Winter Flowering.

Double Annual Early Wonder. Mixed colors............ 


\section{GIANT SWEET PEAS}

\section{Winter Flowering}

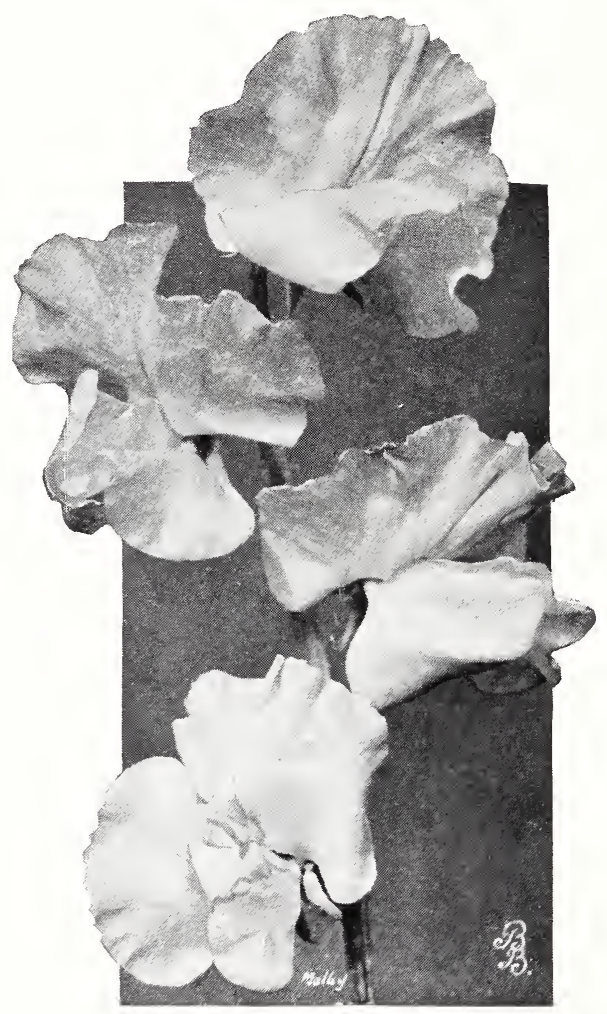

Sweet Pea, Winter Flowering

A valuable race of early-flowering sweet Peas, which from an August sowing in pots will give an abundance of bloom under glass from Christmas onwards. On account of their delicious perfume, sweet Peas are particularly welcome during the dark days of Winter.

\section{Three New Varieties}

of great merit for their vigorous growth, length of stem, and size of flower.

Blue Bonnet. Deep blue of enormous size without

the slightest trace of mauve

Pkt.

Majestic Rose. Immense deep brilliant rose pink of the popular color of 'Zvolanel's rose

$\$ .50$

valencia. Bright orange, superior to any other orange variety

\section{Popular Standard Sorts}

Bircl. A charming shade of blue Oz. Pkt Early King (Improved). A glowing, rich, bright crimson 


SELECTED FLOWER SEEDS

WINTER FLOWERING SWEET PEAS-Continued

Glitters. A bright fiery orange $\quad$ Oz. $\quad 1.00 \quad$ Pkt

Imperial Pink. A clear pink of enormous size,

of vigorous growth, long stems. . . . . . . $1.50 \quad .25$

Jeanne Mamitsch. A beautiful shade of rose pink

Iavenaer king. A rich true deep lavender 1.00

Mrs. Kerr. The best early flowering salmon $1.50 \quad .25$

Pink Profusion. A sparkling shade of rich pink $1.50 \quad .25$

Snowstorm Improved. Pure white, large and of fine form

True Blue. A charming shade of true blue ...... $1.00 \quad .25$

Yarrawa. Pleasing shade of bright rose pink $1.00 \quad .25$

Mixed, All Colors

(Any variety not listed will be procured to order at advertised prices.)

\section{HARDY PERENNIAL FLOWER SEEDS}

\section{For Mid-Summer Sowing}

If more complete descriptions of the following are required, please refer to our General Spring Catalogue.

Varieties marked thus (*) are recommended for edgings and rock gardens.

ACANTHUS Mollis. Stately hardy plant, with large

decorative leaves, handsome, tall flower spikes.

ACHILIEA Ptarmica fl. pl. The Pearl $1 / 8$ oz. $\$ 1.00 \quad .25$

ACONITUIM (Monk's Hood). $4 \mathrm{ft}$.

Napellus. Blue and white.......... 1/4 oz. $\$ 1.00 \quad .15$

Pyramidatum. Blue... ….................. $1 / 4$ oz. $\$ 1.00 \quad .15$

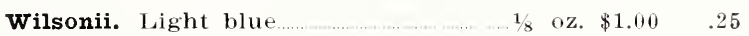

*AETHIONEMA grandiflorum. A very elegant plant which succeeds well on the rockery. Rosy flowers, produced in long racemes. 12 to $18 \mathrm{in.}$

AGATHEA coelestis (Blue Daisy). Flowers sky-blue with yellow disk

AGROSTEIMIMA coronaria. (Rose Campion.) Dark blood-red. 2 ft................ $1 / 4$ oz. $50 \mathrm{c}$

coronaria alba. White …….............. $1_{4} \mathrm{oz}$.

cœli-rosa. H. A. Free flowering with bright rose flowers. 18 in............................ $1 / 4$ oz. $50 \mathrm{c}$

ALIwOODII. New race of hardy plants belonging to the Dianthus family

*Alpinus. Suitable as rock and alpine plants. Height about 6 inches. Colors chiefly pink, white and purple shades

AISTROgimeria Chilensis. Spotted Lily-like flowers of various shades of pink, rose, red and yellow. Height 2 to 3 feet.

inixed color's

*Aryssum Saxatile. Yellow, 1 ft......... 1/4 oz. $75 \mathrm{c} .15$

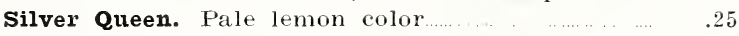

ANCFusa Italica, Dropmore var. Deep blue, 4 to

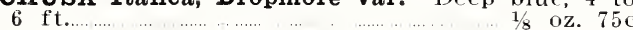


ANEMONE. Beautiful spring flowers, valuable for cutting.

*coronaria, Single De Caen

Plkt.

* St. Brigid. Poppy flowered

* Creagh Castle Strain. The flowers are extremely large and the rang of colors exceptional

*alpina. A lovely species for the rock garden. Flowers white tinted slaty blue. $1 \mathrm{ft}$...

*pulsatilla (The Pasque Flower). Large purple flowers with yellow anthers, covered with silky hair's on outside. 9 in.

*ANTrEIIS montana. Pretty small flower, like a White Chrysanthemum. Height, 6 in. Excellent perennial border plant............. oz. $75 \mathrm{c}$

rinctoria Kelwayi. Improved strain, with bright yellow, Daisy-like flowers. June to September. $11 / 2 \mathrm{ft}$. $1 / 8 \mathrm{oz} .50 \mathrm{c}$

AQUILEGIA (Columbine)

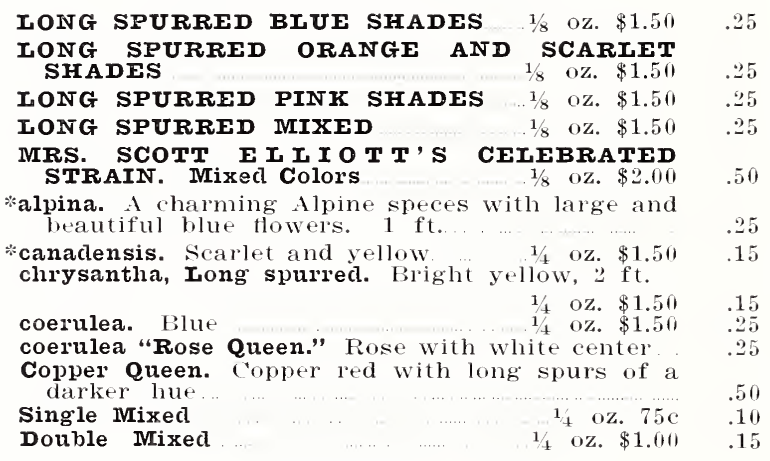

*ARABIs alpina (Rock Cress). White. 6 in.

Rosea. Vivid red

ARCTOTIS Scapigera. A half-hardy, dwarf herbaceous species from South Africa. Of vigorous growth and produces large flowers in a great variety of colors. Very showy and effective.

*armeria formosa (Sea Pink). Lavender Pink

*formosa gigantea. Taller than the preceding

*Ruby. Forms neat tufts of evergreen foliage, flower's, $2 \mathrm{ft}$. high, bright rose pink

WARENARIA caespitosa. Dwarf rock plant, bright green foliage, with tiny white flowers, from Nay to July

* grandiflora. Effective rock plant of trailing habit, large pure white flowers in Spring. 6 in.

*montana. Excellent rock plant; it forms mounds of foliage which are covered with white flowers. $\delta$ in.

ASTER Delavayi. A unique hardy perennial Aster. Nothing more beautiful can be imagined than this wonderful species. Its main feature is possibly the jet black center

alpinus Goliath. A charming little Alpine, 6 inches high, producing in July dainty lilac flowers with golden centers

*alpinus, Nancy Perry. Fine variety with lavenderblue ray florets, golden centre, 6 in.

*subcoeruleus. A Himalayan species of compact habit bearing deep blue flowers

Farreri. A lovely soft tone of violet-mauve, greatly enhanced by a large golden-orange disc. 2 to $3 \mathrm{ft}$. May-June.

Hardy Irixed (Michaelmas Daisy). Fall-flowering, splendid for cutting $1 / 8$ oz. $\$ 1.00$ 
*AUBRIETIA. Excellent for rock-work and edging,

9 inches.

graeca. Purple; trailing

henclersoni. Large rich purple flowers

leichtlini. A charming variety, with very bright rosy crimson flowers

large flowered hybrids. Exceptionally fine colors. purpurea. Purple

violet queen. Dark violet, large flowers

*AURICULA (Primula auricula). A well-known favorite; choice mixed

BAPTISIA australis. Producing spikes of peashaped blue flowers. $2 \frac{1}{2} \mathrm{ft} \ldots \ldots \ldots \ldots .1 / 4$ oz. $\$ 1.50$

*BEIIIs. Double Daisy. Beautiful spring flowers, suitable for edging. $1 / 2 \mathrm{ft}$.

IMONSTROSA, Giant White $\quad 1 / 8$ oz. $\$ 1.50$

MONSTROSA, Giant Red $\ldots . . .1 / 8$ oz. $\$ 1.50$

MONSTROSA, Giant Rose …….1/8 oz. $\$ 1.50$

MONSTROSA, Giant Mixed … $1 / 8$ oz. $\$ 1.50$

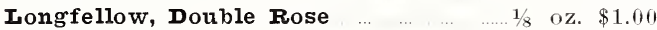

Snowball, Double White $1 / 8$ oz. $\$ 1.00$

Double IVrixed $\quad . . . . . .1 / 8$ oz. $\$ 1.00$

BOCCONIA japonica. (Flume Poppy.) Flowers, creamy white. $4 \mathrm{ft}$.

BOLTONIA Asteroicles. Showy perennials, closely resembling Hardy Asters, flowers pure white. August and September. $6 \mathrm{ft}$.

Iatisquama. Flowers pink, tinged with lavender. August and September. $6 \mathrm{ft}$.

CALIIRHOE involucrata (Poppy Mallow). A showy, trailing perennial, bright crimson saucer-shaped flowers

\section{CAMPANULA}

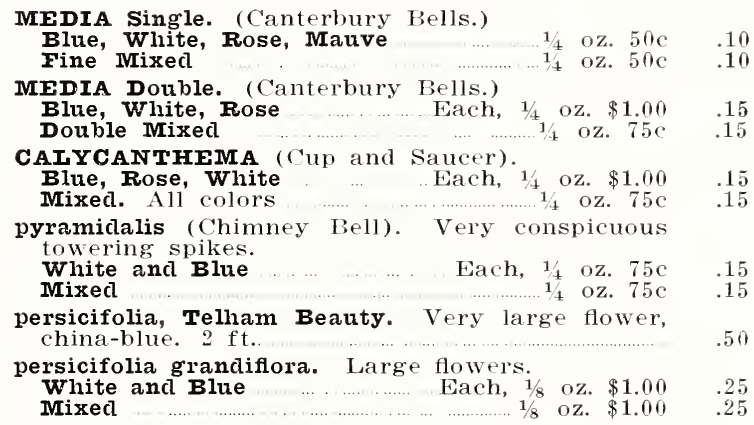

\section{Dwarf Campanulas for Rock Work}

$\begin{array}{llllll}* \text { carpatica. Blue, showy. } 1 \mathrm{ft} & 1 / 4 & \text { oz. } 50 \mathrm{c} & .15\end{array}$

* carpatica alba. White. $1 \mathrm{ft} \ldots \ldots \ldots . .1 / 4$ oz. $50 \mathrm{c}$

*Garganica. A pretty trailing species, pale blue flowers with white centers. 4 inches..

* Mrirabilis. A most beautiful species from the Caucasus, large pale blue flowers. 3 in.

* Pusilla. A charming dwarf Harebell, forms tufts of foliage, covered with dainty flowers in various shades of blue, 3 in.

* RAINERI. Forms creeping masses of dark green foliage, covered with a profusion of saucershaped, pale blue flowers. 4 in.

* Rotundifolia (Scottish Blue Bell). Slender, branching stems. Flowers pale blue and bellshaped

*Turbinata. Tufts of neat foliage, and erect, deep blue, cup-shaped flowers. 6 inches.

Special collection, 6 varieties, for Rock Gardens, $\$ 1.50$. 


\section{PERENNIAL FLOWER SEEDS}

*CANDXTUFT (Iberis).

Sempervirens. White flowers $\quad 1 / 8$ oz. $\$ 1.00 \quad .25$

Gibraltarica. Beautiful blush white...1/4 oz. $\$ 1.00 \quad .15$

CATANANCHE caerulea. Beautiful blue flowers. June to August. $2 \mathrm{ft}$.

* CARNATION. Early Dwarf vienna. Same type as the Grenadin. Choice Mixed ...... oz. $\$ 1.00$ *Grenadin. Bright scarlet; dwarf . 1/4 oz. $\$ 1.00$ * Grenadin white. Pure white, dwarf $1 / 4$ oz. $\$ 1.00$

Haxdy Borcler Double IMixed. A good hardy strain for outdoor culture $\ldots . . . .1 / 4$ oz. $\$ 1.00$

CENTAUREA (Cornflower).

Irontana. Blue, $2 \mathrm{ft}$.

Montana Alba. White, $2 \mathrm{ft}$.

*CERASTIUIM Tomentosum. White, $3 / 4$ ft...1/8 oz. $\$ 1.00$

CHELONE Hybrida Torreyi. Showy bedding plant, with brilliant scarlet flowers. June to Aug. $2 \mathrm{ft}$. $1 / 8$ oz. $75 \mathrm{c}$

Hybrida Mixed. The colors vary from light pink to deep red and violet, $2 \mathrm{ft}$............... oz. $60 \mathrm{c}$

* Cheiranthus Allioni (Siberian Wallflower). Showy rock plants with bright orange flowers blooming all Summer. $1 \mathrm{ft}$.. $\quad 1 / 4$ oz. $75 \mathrm{c}$

*linifolius. Alpine Wallflower. A charming dwarf alpine, producing freely its pretty mauve, fragrant flowers. May, June. $1 \mathrm{ft}$.

CHRYSANTHEMUIM (Maximum)

King Edward VII. Pure white

IVrs. C. Iothian Bell. Pure white

Shasta Daisy. White

Mayfield Giant. Large, snow white

CIMICIFUGA racemosa. Tall, hardy and ornamental: suited for the back of borders or for partially shaded places; white racemes of Howers. 5 to $6 \mathrm{ft}$. June-July

Commerin A Coelestis. A fine border plant, producing an abundance of bright sky-blue flowers. It is tuberous rooted, and should be lifted and stored in Autumn. 11/2 feet

COREOPSIS (Perennial Calliopsis).

* Auriculata "Superba." An improved form, several tones deeper than the ordinary riandiflora, with a serrated band of brownish-red

lanceolata. Bright yellow

CowsrrP. A tavorite for the spring garden. $1 \mathrm{ft}$. Hinest mixed

CRUCIAINEILA. Stylosa. A plant of trailing habit and rapid growth, bright rose-colored flowers; very suitable for the rock garden. 6 in.

CUPHEA (Cigar Plant). Half-hardy perennial, useful for bedding. $1 \mathrm{ft}$.

platycentra. Scarlet and purple

\section{DELPHINIUM (Larkspur)}

"WREXHAIM" STRAIN. The seed of these beautiful Delphiniums we import direct from a celebrated English grower. Considered the finest type of all. Colors range through the entire range known to delphiniums.

3 Pkts. $\$ 5.00 \$ 2.00$

BURNETT'S GOID MEDAL HYBRIDS. Choice mixed $1 / 8$ oz. $\$ 2.50$ belladonna. Improved. Single flowers of a clear turquoise blue $1 / 8$ oz. $\$ 1.00$ pellamosa. Deep blue ……1/ oz. $\$ 1.00$ elatum (Bee Larkspur). Clear blue... $1 / 4$ oz. $50 \mathrm{C}$ formosum. Rich blue, with white center. $3 \mathrm{ft}$.

nudicaule. Scarlet $1 \frac{1}{2} \mathrm{ft}$.

$1 / 4$ oz. $\$ 1.00$

Zalil (Hardy Yellow Larkspur)

chinensis. Light Blue, Dark Blue, white and mixed $\mathrm{Each}, 1 / \mathrm{Oz} .50 \mathrm{c}$

Blue Butterfly. Rich blue, if sown early will

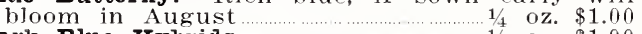

Dark Blue Hybrids $\quad 1 / 8$ oz. $\$ 1.00$

Medium Blue Hybrids $\quad 1 / 8$ oz. $\$ 1.00$

Iight Blue Hybrids $1 / 8$ oz. $\$ 1.00$

$\begin{array}{lll}\text { Inixed Hybrids } & 1 / 8 \text { oz. } \$ 1.00 \\ \text { Inixed } & \$ 2.00\end{array}$ 


\section{PERENNIAL FLOWER SEEDS}

Continued

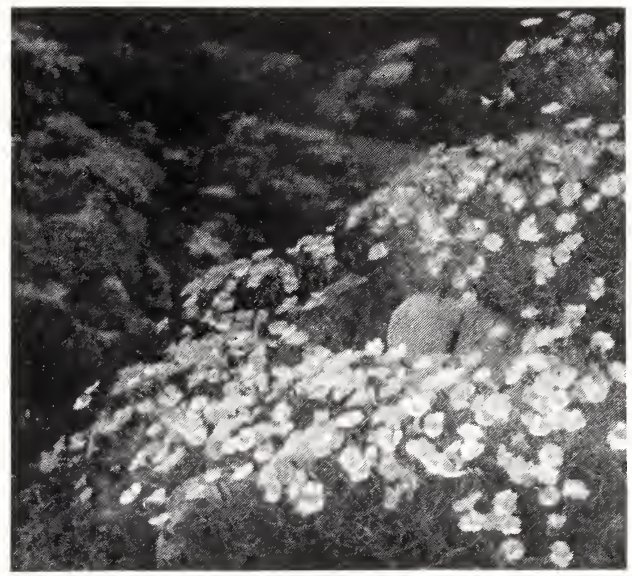

Dianthus, Rock Hybrids

\section{*DIANTHUS (or Pinks)}

Allwoodii. See Allwoodii.

Plumarius (Pheasant's Eye).

Single IMixed $\quad .1 / 4$ oz. $50 \mathrm{c} \quad .15$

Double IMixed $1 \frac{1}{4}$ oz. $75 \mathrm{c} \quad .15$

Semperflorens (Perpetual Pinks). Mixed.

Scoticus. Double Scotch Pink, Mixed .25

\section{DWARF ROCKERY VARIETIES}

*Dianthus Alpinus (Alpine Pink). Rosy Pink. 4 ins.

*Arenarius (Sand Pink). White, fringed. Very free. 4 in.

*Caesius (Cheddar Pink). (Bright pink; fine for dry bank, rockeries and old walls. 6 in.

* Deltoicles (Maiden Pink). Trailing variety; flowers pink with dark circle. 6 in.

*Deltoicles Alba. White, $\delta$ in.

*Neglectus. Tufts of dark green foliage, brilliant carmine rose flowers, 3 in

*sylvestris. A rock garden gem with large soft pink blossoms. 6 in.

* New Rock Hybricls. A beautiful mixture of colors. Charming for rock garden or walls. 6 in. Collection, 6 Rock Garden Varieties, \$1.25.

DIGITAIIS (Foxglove).

gloxinioicles. Spotted varieties.

Pure White, Rose, Rich Purple Each, 1/1 oz. $50 \mathrm{c}$ Mixed. All colors $1 / \mathrm{oz} .35 \mathrm{e}$

Isabellina. A beautiful sulphur-yellow

maculata superba. An extra choice strain of beautifully spotted sorts …… oz. $75 \mathrm{c}$

monstrosa (Mammoth Foxglove). Long spikes, surmounted by one enormous flower; very distinct, mixed $1 / 4$ oz. $75 \mathrm{c}$

The Shirley. Colors ranging from white to dark rose, handsomely blotched and spotted.

Iutzii (New). Distinct salmon

*DODECATHEON Meadia. (American Cowslip.) For sheltered positions in the rock garden; rosypurple flowers on stems 9 inches high

* Doronicuiv caucasicum. (Leopard's Bane.) Clear yellow, daisy-like flowers

ECHINOPS Ritro. (Globe Thistle.) A hardy perennial with blue, thistle-like flowers. $3 \mathrm{ft}$. 
*EDEIWEISS (Leontopodium alpinum). The interesting white-leaved plant so eagerly sought by tourists in the Swiss Alps. 6 in.

EREMIURUS. Gold Medal Hybrids. Stately plants with long spikes of various colored flowers. $6-8 \mathrm{ft}$.

*ERIGERON speciosus. Pale mauve flowers, gold centers. $1 \frac{1}{2} \mathrm{ft}$.

*ERINUS Alpinus. A charming Spring-flowering plant with pale purple flowers. Valuable for Rock Garden. 2 ins...

ERYNGIUM Amethystinum (Sea Holly). Ornamental hardy perennial, blue flowers. $4 \mathrm{ft}$.

*ErysImUM Linifolium. (The Mauve Alpine Wallflower.) Produces a profusion of flowers of a bright, clear mauve.

*Rupestre. (The Fairy IVallflower.) A lovely Alpine plant producing pale yellow flowers abundantly in early spring. 6 in.

EUPATORIUIM Fraseri. A pretty, hardy plant; producing elusters of white flowers; fine for cutting. $2 \mathrm{ft}$.

GAIJIARDIA Portola Hybrids. (New.) Shades of bronzy red, golden tipped .......1/4 oz. $\$ 1.50$

kermesina splendens. Rich crimson, narrow yellow border

grancliflora "Dazzler." Bright golden-yellow with rich maroon-red center …….........1/4 oz. $50 \mathrm{c}$ grandiflora maxima. Golden yellow ......1/4 oz. $35 \mathrm{c}$ Giant Hybrids, Mixed

$1 / 4$ oz. $\$ 1.00$

GAIEGA. (Goat's Rue.) Fine hardy horder plant, covering itself with spikes of pea-like blossoms. $3 \mathrm{ft}$.

Hartlandi. White and lilac, variegated foliage

officinalis. Blue

Pkt.

*GENTIANA acaulis (Blue Gentian). Intense blue bell-shaped flowers. $6 \mathrm{in}$.

*GEUMr. Mrs. J. Bradshaw. Large, double, scarlet flowers. $1 / 8$ oz. $75 \mathrm{c}$

Orange Queen. Large and free-blooming

Iady Stratheden. Rich golden yellow.

Coccineum. Single, bright orange scarlet

GYPSOPHII, Paniculata. White flowers, fine for bouquets. $2 \mathrm{ft} \ldots \ldots \ldots \ldots \ldots \ldots . .1 / 4 \mathrm{oz} .50 \mathrm{c}$

Paniculata fl. pl. Double flowering Baby's Breath. $1 / 8$ oz. $75 \mathrm{c}$

*Repens. A pretty dwarf trailing species for the rockery. It has pinkish-white flowers, 6 in.

1/8 oz. $\$ 1.00$

* Repens Alba. Pure white. 6 in. $\quad .1 / 8$ oz. $\$ 1.00$

HELENIUIM. Very fine for cutting.

Bigelow. Flowers bright yellow, black centre $\quad .15$

autumnale. Pale yellow

Riverton Gem, orange, dark centre.

*herianthemum. (Rock Rose, Sun Rose.) Dwarf evergreen plants for rock gardens, walls, or for clothing dry banks. Also useful for edging in the herbaceous border.

Mutabilis, Mixed ............. oz. $50 \mathrm{c}$

HEIIANTHUS (Sunflower). Perennial Varieties, Mixed $1 / 8$ oz. $\$ 1.00$

HEIIOPSIS Pitcheriana. (Orange Sunflower.) Deep golden yellow single flowers $\ldots \ldots \ldots . . .1 / 4$ oz. $50 \mathrm{c}$

*HEUCHERA. Fine for borders or rock garden. $12-18$ in.

*brizoides, distinct new species dwarf habit, pale rose flowers

*-gracillima, fine new form with slender, graceful pink sprays

* Sanguinea splendens. Bright scarlet-crimson

*-Alba. White 25

*Hybrida Grandiflora. Many choice varieties, Mixed $\quad .25$ 
HIBISCUS (Marshmallow). 2 to $4 \mathrm{ft}$.

Pkt.

moscheutos (Swamp Mallow). Flowers like single Hollyhocks but much larger.

Roseus. Pink $\ldots \ldots \ldots \ldots . . .1 / 4$ oz. $50 \mathrm{c}$

grandiflorus Rainbow Hybrids. New giant flowering Marshmallows. Very large flowers in vari-

ous colors …........... 1/4 oz. $60 \mathrm{c}$

\section{HOLLYHOCK.}

Chater's Double, Bright Pink, Canary Yellow, Blood Red, Crimson, White, Rose, IVIaroon.

Double Fine Mixed

Single IVixed. Choice colors

type, of delicate tints

INCARVILLEA Delavayi (Hardy Gloxinia). Pink. $2 \mathrm{ft}$.

Variabilis Hybrids

*INUIA Glandulosa grandiflora. (Flea Bane.) A very fine hardy border plant, large golden yellow flowers. June to August.

LATHYRUS latifolius (Everlasting Pea.) Ornamental climber for trellises, etc. $6 \mathrm{ft}$.

White Pearl, Pink Beauty …........Each, 1/4 oz. $60 \mathrm{c}$ Finest Mixed

LAVENDER. (Lavandula.) Much prized for the delicious fragrance of its violet flowers. $2 \mathrm{ft}$.

Spica. Conmon broad leaved.......
vera. True lavender...

LIATRIS spicata (Blazing Star). Slender spikes densely crowded with rosy purple flowers. 4 to $5 \mathrm{ft}$.

Pycnostachya (Kansas Gay Feather). Rich purple flowers; most effective in the garden and splendid for cutting. 4 to $5 \mathrm{ft}$.

*IINARIA (Toad Flax). Alpina. A brilliant little rock plant. with glaucous grey leaves, flowers violet with orange lip

IMacedonica Speciosa. The flowers resemble large golden yellow snapdragons, borne on stems averaging three

*IINUIM. flavum. Golden yellow

*perenne. Blue Flax .1/4 oz. $35 \mathrm{c}$

*alpinum. Dwarf, spreading; lavender blue; fine for rock gardens

LOBELIA cardinalis (Cardinal Flower). A native variety, with spikes of brilliant scarlet flowers; $3 \mathrm{ft}$.

hybricla. Various shades of scarlet

Queen Victoria, scarlet

\section{LUPINUS}

polyphyllus, Blue
Rose
White
Choice Irixed
Lavender Queen. Lavender, tinted rose $\begin{gathered}1 / 4 \\ \text { oz. }\end{gathered} 50 \mathrm{c}$
IMoerheimi. A beautiful variety; long spikes
of pink and white flowers

New Sweet-Scented Hybrids. A wonderful new strain, in shades of blue, mauve, pink, etc.

Golden Spire. Fine golden yellow

Arboreus (Tree Lupine). Fine hardy shrubby plant, covering itself with its long flower spikes.

"Snow Queen." Pure white.

$1 / 4$ oz. $75 \mathrm{c}$

*LYCHNIS. (Campion.) For massing in beds and borders. $2 \mathrm{ft}$.

*Alpna. Dwarf rose pink. Splendid rock plant

*Arkwrightii. Beautiful, new hybrids, many distinct and attractive shades..................... 0 z. $75 \mathrm{c}$

*chalcedonica. Scarlet flowers ............... $1 / 8$ oz. $50 \mathrm{c}$

* Haageana lybrida. Mixed ……................ 
*ITTHRUM roseum superbum. (Loosestrife.) Spikes of rosy pink flowers

Pkt.

MAILOW, Acer-leaved. A handsome quick-growing perennial from oregon, about $2 \frac{1}{2}$ feet high, bearing long spikes of pale rose blossoms about

2 inches across

MECONOPSIS Baileyii. A new perennial Poppy, discovered in 'Thibet. Of a glorious sky-blue

Cambrica (The Yellow Welsh Poppy). Showy variety with pale yellow flowers, fine for rockwork

IVYYosotrdeuIV Nobile (The Giant Forget-Me-Not of the Chatham Islands). Large heads of beautiful blue flowers, edged white. Height $1 \frac{1}{2} \mathrm{ft}$.

*MYOSOTIS (Forget-me-not). Height 6 to $12 \mathrm{in.}$

*BURNETT'S WTITER BLOOMING. Large flower, dark blue, recommended for Winter bloom, indoors

*alpestris. Blue. $\quad .1 / 4$ oz. $75 \mathrm{c}$

ROYAI BIUE. Rich indigo-blue... 1/4 oz. $\$ 1.00$

*VICTORIA. Azure blue. Fine for pots. $6 \mathrm{in}$.

1/4 OZ. $\$ 1.00$

*lissitiflora. Sky-blue, 34 ft. $\quad \ldots 1 / 8$ oz. $\$ 1.00$

* palustris. Blue $1 / 2 \mathrm{ft}$. $1 / 4 \mathrm{oz} .75 \mathrm{c}$

*palustris semperflorens. Perpetual flowering. Eright blue. 6 in. $\quad 1_{4} \mathrm{oz} \$ 1.00$

* FY BRIDA RUTH F'ISCHER. Very large, pale blue flowers. 6 in.

*Choice IMixed

$1 / 4$ oz. $50 \mathrm{C}$

*NEPrTA IVIussini. An invaluable border or rock plant. Lavender violet blooms. $1 \mathrm{ft}$.

*NFREERA (Madder-worts).

depressa. Extremely pretty for pots or rockery, dense tufts, thickly studded with tiny scarlet berries

OENOTIIRA Rraseri. large yellow

"clutei." This handsome new biennial Evening Primrose is a native of Arizona. Bearing in great profusion large flowers of a soft yellow hue

Printignon. Burnett's Giant Flowered Hybrids Mixed

$1 / 16$ oz. $\$ 1.00$

PEREzia Inultiflora. Branching umbels of starshaped flowers, of a clear porcelain blue

PzISOSTrGra Virginica. (False Dragon-head.) The delicate pink flowers are much esteemed for cutting $1 / 4 \mathrm{oz} .75 \mathrm{c}$

virginica grandiflora alba. Large white flowers.

PLATXCODON Mariesi (Japanese Bell Flower). Deep blue $\ldots 1 / 8$ oz. $75 \mathrm{c}$

Grandiforum. Light blue .............. $1 / 8$ oz. $50 \mathrm{c}$

Album. White

PyLox Decussata (Hardy Perennial Phlox).

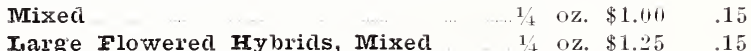

POLEMOINIU⿴囗十 Coeruleum grandiflorum. (Jaeob's Ladder or Greek Valerian.) Clusters of handsome blue flowers

Grancliflorum album. Pure white. ${ }_{ \pm}+$oz. $\$ 1.00$

POLYANTHUS (Primula elatior).

* Mrunstead Strain. Producing wonderful shades of yellow as well as pure white flowers

*Gold Iaced. Brilliant colored flowers with distinct yellow edges

*Choice IMixed 


\section{POPPY (Papaver)}

ORIENTAIE APRICOT QUEEN (New). Beautitul apricot shade

IIrs. Perry. Brilliant orange scarlet

Salmon Queen. Salmon pink

Scarlet. Scarlet, spotted black ……1/8 oz. $50 \mathrm{c}$

IVixed Hybrids. Very choice ……….......1/8 oz. $75 \mathrm{c}$

Bracteatum. Brilliant scarlet........................

*NUDICAULE or Iceland Poppies.

*White, Scarlet or Yellow … Each 1/4 oz. $75 \mathrm{c}$

*Ivixed . $1 / 4$ oz. $50 \mathrm{c}$

* Baker's sunbeam. An improved and glorified strain. very large flowers.

* Coonara Pinl. A delightful pink variety of recent introduction

* Thibet. Flowers brilliant orange, quite different from anything else that can be found in Nudicaule Poppies

* Alpine Inixed (Papaver Alpinum). A charming dwarf variety for rock work, 6 inches

POTENTILA. Blooming from June to August. $11 / 2-2$ it.

Single IVixed

IVIiss willmott. (New.) Beautiful dwarf pink variety, excellent for rock work

Double ivrixed

* Primrose. (Primula Vulgaris.) Amongst early Spring-flowering plants the hybrid Primrose occupy a prominent place.

*Dean's Choice Hybrids, Mixed

* Hybricl Blue. Shades vary from lavender to deep violet

* Common Yellow. (Primula Acaulis.) Well-known charming single primrose. 6 in. ... 1/8 oz. $\$ 1.50$

\section{*PRIMULAS, Hardy Varieties}

*Bullesiana Kybricls. These Hybrids are free Howering, adapted both for out-door and greenhouse culture

* Cashmiriana. A fine species with large globular heads of deep violet blue flowers; excellent for rockwork. $1 \mathrm{ft}$.

*Cortusoicles. A distinct Siberian species, with sott, wrinkled, lreart-shaped leaves. Flowers deep rose. 10 in.

*Denticulata Hybricls. Many new shades from white to lilac, rose purple, and blue. $1 \mathrm{ft}$.

*Pulverulenta, Bartley strain. A new strain of hardy Primula, embracing all shades of pink, rose, and blush

Florindae. This giant primrose stands 3 to 4 feet high with broad leaves, and bearing from June to August 60 to 80 terminal pendant flowers, bright yellow

* Japonica, Finest rrixed. Large flowers, varying in shade from white to crimson

PYRETHRUIV (Persian or Painted Daisy). Delightful plants with daisy-like blossoms on long graceful stems. $1-2 \mathrm{ft}$.

Roseum. Single IVixed Hybricls …... 1/8 oz. $\$ 1.00$

Roseum. Double IVixed Hybricls ... $1 / 8$ oz. $\$ 2.00$

REHIMANNIA angulata. Gloxinia-like flowers of rosy-purple with yellow throat. $3 \mathrm{ft}$.

ROCKET, Sweet (Hesperis). Excellent for naturalizing among shrubbery.

Purple
White
IVixed Colors

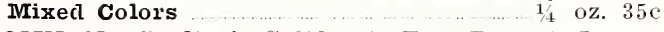

ROMINEX A Coulteri (California Tree Poppy). Large, single white flowers, centers yellow. $3 \mathrm{ft}$.

RUDBECKIA (Cone Flower).

hirta. (Black-eyed-Suzan.) Golden yellow. $3 \mathrm{ft}$.

Purpurea Grandifora. (Purple Cone Flower.) $4 \mathrm{ft}$.

Newmanii. Large, golden yellow, with velvety

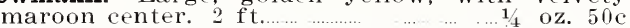

*SAPONARIA. Ocymoides splendens. Elegant trailing perennial with pretty rose-colored flowers suitable for rockeries .................................1/4 oz. $35 \mathrm{c}$ 
SCABIOSA. Handsome border plants flowering the entire season.

Caucasica. House's Sensational Strain. In this hybrid strain will be found colors ranging from white to the darkest blue

Caucasica. Soft blue; 3 feet.……1/8 oz. $\$ 1.00$

Caucasica Alba. Pure white …….......1/8 oz. $\$ 1.25$

Japonica. Lavender blue

* SEDUIM acre. Trailing plant forming a regular green carpet. Flowers bright yellow. 4 in.

Imixed Varieties. Useful for covering rock or old walls; 4 in.

SIDAICEA, New Hybrids. Including shades of rose, pink, red, salmon, lilac and heliotrope. $2 \mathrm{ft}$.

Rosy Gem. Beautiful deep rose

*SIIENE alpestris. Delightful little white rock plant of easy culture

GTATICE Iatifolia. Hardy perennial with large, branching heads of clear mauve Howers, $2 \mathrm{ft}$.

gTokESIA cyanea (Stoke's Aster.) Flowers large and handsome. 12 to $18 \mathrm{in}$. Blue. ${ }_{1} \mathrm{oz} . \$ 1.00$

cyanea alba. A pure white form … 1/4 oz. $\$ 1.25$

\section{SWEET WILLIAM}

Burnett's Diadem. Beautiful rich deep crimson

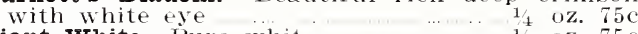
Giant white. Pure white ........... $1_{4}$ oz. $75 \mathrm{c}$ NEWPORT PINK. A distinct color $1 / 4$ oz. $\$ 1.00$ Pink Beauty. Fine deep pink ${ }_{1+}$ oz. $75 \mathrm{C}$ Scarlet Beauty. Rich scarlet ${ }_{4} \mathrm{oz} .75 \mathrm{c}$ Holborn Glory. (Auricula-eyed.) superb range of colors $\quad 1_{4}^{1}$ oz. $50 \mathrm{C}$

Single Fine, IVrixed $\quad \ldots \ldots \ldots . . .1$ oz. $30 \mathrm{c}$

Double Fine, Irixed $\quad \cdots \ldots . . . .14$ oz. $50 \mathrm{C}$

THALICTRUIVI adiantifolium. A graceful plant with tinely cut foliage resembling the Maidenhair fern

dipterocarpum. Graceful species with pretty rosypurple flowers

TRITOIVA (Torch Flower, Red Hot Poker).

Stark's Hybrids. The colors embrace yellows and salmons to deep erimson. "2 to $4 \mathrm{ft}$.

TROIIIUS Europaeus. (Globe Flower.) Bright yellow globular flowers, $2 \mathrm{ft}$..... $1 / 8 \mathrm{oz} .60 \mathrm{c}$

VAIERIAN (Garden Heliotrope). Admirable for wild gardens and rockwork. $2 \mathrm{ft}$.

Rubra. Bright red Howers in panicles

white. A white form of the above

VERBASCUIV Harkness Hybrics. Immense spikes, pure yellow Howers. 5 ft.

Miss Willmott. A lovely white Verbascum 5 to 6 feet. Hardy biennial

Phoeniceum. One of the prettiest species of Verbascum for the herbaceous border

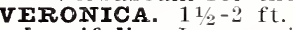

longifolia. Long spikes of rich blue flowers.

spicata. Bright blue flowers.... …... $1 / 4$ oz. $75 \mathrm{c}$

vroLA. "Blue Gem" (Jersey Gem). Pleasing deep violet blue. Blooms profusely for a long period

Apricot. Apricot yellow, tinged orange; distinct variety

*Admiration. Dark blue, blotched 1/t oz. $\$ 1.50$

* Iutea. Yellow $1 / \mathrm{oz} . \$ 1.50$

* Iutea Splendens. Orange........ 14 oz. $\$ 1.50$

*Papilio. Lilac ……........

* Perfection. Blue

* Purple Queen. Dark blue 1 oz. $\$ 1.50$

* White Perfection. White $\quad 14$ oz. $\$ 1.50$

* Finest Irixed …............. oz. $\$ 1.25$

*G. Wermig. (New.) Long stems, violet blue flowers

*WALIFLOWER. Well known deliciously fragrant flowers.

* Single Iarge Flowering.

Blood-Red, Golden Yellow, IMixed.

*Double Iarge Flowering, Mixed Eacn, ${ }_{1 / 4}^{1 / 4}$ oz. $\$ 0 \mathrm{c}$

SEEDS OF ALPINE AND ROCK PLANTS Suitable for Rock Gardens, etc.

Collection 12 varieties 


\section{PEONIES}

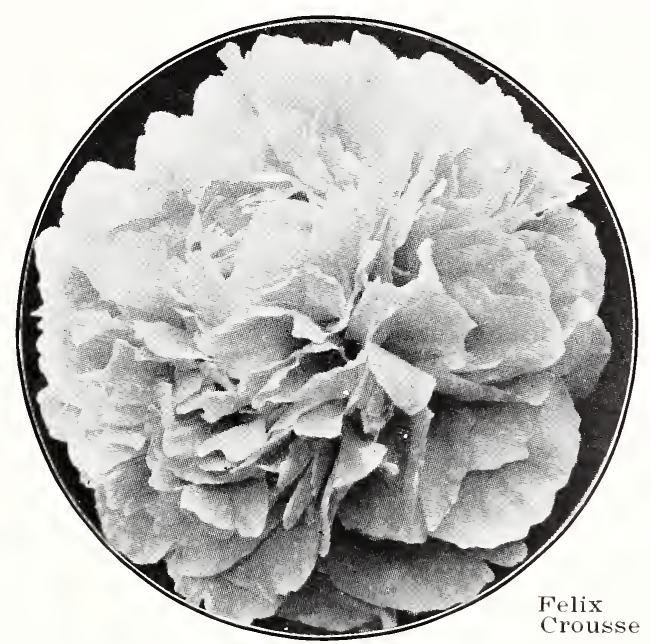

For best results, transplant during September and october covering the crowns with but two inches of soil. In manuring avoid direct contact with roots. Mulch lightly for winter protection.

Extra-strong roots, 3 to 5 eyes.

ADOLPH ROSSEAU. Deep garnet. Early midseason large

AIBATRE. Milk-white, tinged Lilac. Large, fragrant

ALBERT CROUSSE. Salmon-pink, fragrant, late...

ALEXANDER DUIMAS. Midseason. Violet-rose, white collar, fragrant, good cut-flower variety.

ALSACE IORRAINE. Creamy-white overlaid with pale yellow. Extra large, late.

ASA GRAY. Pale-pink, dotted lilac, midseason

AVALANCHE. Cream-white, tinted lilac, flecked carmine, midseason

AVIATOR REYMOND. Cherry-red, midseason

Each $\$ 1.50$

BARONESS SCHROEDER. Flesh-white, large, fragrant, long bloomer, best of the "old Timers." midseason

1.00

1.50

.75

1.50

2.00

1.00

2.00

1.50

CHERRY HILL. Deep-garnet, strong stem, conspicuous marking, midseason

CHRISTINE RITCHER. Violet-rose, of unusual high merits and rating

CLAIRE DUBoIse. Satiny-pink, large, late midseason

COURONNE D'OR. Milk-white with yellow tints, tipped carmine, large, late...

DUCHESSE DE NEMOURS. White with lemonyellow center, fragrant, good cut-flower, early...

DORCFESTER. Hydrangea-pink, unique color

EDUIIS SUPERBA. Dark-pink, large, fragrant, good cut-flower, early

EIIZABETH B. BROWNING. Pure-white, red markings, fragrant, of wonderful form, late.

ELWOOD PLEAS. Light rose-pink, late. One of the best

EUGENIE VERDIER. Pale Hydrangea-pink, lilacwhite outer petals, fragrant, late, erect.

FEIIX CROUSSE. Brilliant-red, fragrant, midseason

FESTIVA IMAXIMA. Pure white, crimson markings, popular, good cut-flower, immense size, another outstanding "Old Timer"

4.00

7.50

1.00

1.60

.75

1.00

.75

3.50

2.50

1.25

1.00

FRANCES WIILARD. Blush-white, suffused yellow, late midseason

GERIMAINE BIGOT. Pale lilac-rose, with crimson splashes, strong grower, midseason 
GEORGIANA SHAYLOR. Rose-pink, flecked crimson, large, strong grower, very fine, midseason.

ISOLENE. Pale yellow effect, magnificent flower, vigorous grower, exceedingly handsome.

JAMES KEIWAY. Rose-white, with yellow base, deliciously fragrant, early

JUBILEE. Flesh-white, tinged green, very large, midseason

KAPI ROSEFIEID. Dark crimson, very large, strong grower, attractive, midseason

IADY ALEXANDER DUFF. Pale pink, light center, fragrant, rated very high by the Peony Society. midseason

IA FRANCE. Violet-rose, lavender base, fragrant, immense size, a very fine high ranking variety, late

IA TUIIPE. Large lilac white, carmine markings, fragrant, late

IE CYGNE. Milk white, the nearest to perfection, fragrant, extra fine

IONGFELLOW. Cherry-red, golden stamens, dazzling color. Another high ranking variety

IIVINGSTONE. Lilac rose, large, flecked carmine, late

MARGUERITE GERARD. Flesh-pink, fading to

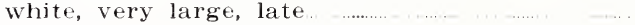

MILTON HIIL. Large lilac rose, excellent for cutting late

MIIE. LEONIE CAIOT. Delicate rose-white, deeper center, carmine tips, distinct, large, late midseason

MIIE. DE VERNEVIILE. Blush-white, flecked carmine, large, fragrant, early

MIME. EMrIE GALLE. Lilac-white, milk-white center, early, rated high

MIME. EMIIE IEMOINE. Milk-white, very large, extra fine, slightly fragrant, midseason

MII. JULES DESERT. Cream-white, shaded flesh and raint yellow, beautiful form, most perfect of the lot, midseason

moNs. DUPONי⿻ Milk-white, crimson splashes in center, large, fragrant, midseason

MONS. JULEs EIIE. Lilac-pink, deep rose base, large fragrant, early, unusually beautiful

MONS. KRELAGE. Dark-pink, tipped silver, large, fragrant, late

MONS. MARTIN CAHUZAC. The darkest peony dark purple garnet, black reflex, midseason

OCTAVIE DEMAY. Delicate-pink, shaded white, charming, fragrant, early

OFFICINAIIS RUBRA PIENA. Rich-red, best of the old fashioned Peonies, brilliant, good cutflower, early

PRIMEVERE. The best yellow, very fragrant, midseason

RICHARD CARVEL. Brilliant crimson, delicate fraglance, early

ROSINE. Pale-lilac, highly rated by the Peony Society, late

SARAF BERNHARDT. Apple-blossom-pink, silver tips, fragrant, admired by all, late

SorangE. Beautiful Cream-coffee color, rated very high by Peony Society and considered one of the three best Peonies in existence, large, late

SOUV. DE IOUIS BIGOT. Bengal-rose, tinged carmine, fringed, large, beautiful, distinct, midseason

THERESE. Soft-pink, the World's best pink, charming, lilac-white center, very large, midseason

TOURANGEILE. Flesh-pink, intensely fragrant, a prize winner at Peoria Flower Show, midseason.

verus. Delicate shell-pink, large, crown type, fragrant, good cut-flower, midseason

WAITER FAXXN. Salmon-rose, has captivating salmon center, fragrant, distinct, midseason

Although we have selected only the most meritorious and popular ones, we can supply any other varieties at advertised prices. 


\section{Burnett's Choice Irises}

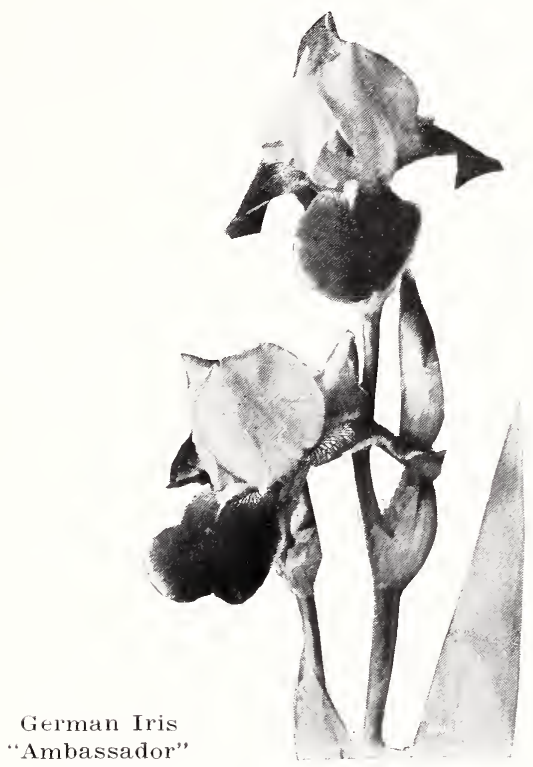

\section{GERMAN IRISES (Fleur de Lis)}

Plant shallow in dry soils with sunny exposure during June, July and August, add Superphosphate to supply the lime needed.

S.-Standard or Upper Petals; F.-Falls or Lower Petals.

AFTERGLOW. Lavender grey shading to buff, yellow haft. 3 for $\$ 1.25$.

ALCAZAR. S.-violet, F.-purple, giant in flower, handsome, height $3 \frac{1}{2}$ ft. 3 for $\$ 1.25$

ANN PAGE. A deliciously scented branching Iris

bearing pale lavender-blue flowers of splendid shape on stout stems; height $3 \mathrm{ft}$. 3 for $\$ 2.00$

AIMASSADEUR. S.-bronzy-violet, F.-velvetymaroon, conspicuous orange beard, immense flower, vigorous, height $4 \mathrm{ft} .3$ for $\$ 1.75$

ASIA. Magnificent immense flowers of fine form and substance borne on strong vigorous stems, bold and upstanding foliage; S.-broad and massive of pale silvery-lavender color with vellow base, F.pale reddish-purple, margined lighter with bright yellow beard; height $4^{1 / 2} \mathrm{ft}$. Each $\$ 1.75 ; 3$ for $\$ 4.50$

CAPRICE. S.-reddish purple, F--deeper, the best "red," height 2 ft. 3 for $75 \mathrm{c}$.

DAIIIA. S.-white, F-reddish purple, most distinct and striking in color, height $2 \mathrm{ft}$. 3 for $\$ 1.25$

HER MAJESTY. S.-pale coppery-pink, darker and heavily veined, most effective pink, height $21 / 2 \mathrm{ft}$. 3 for $75 \mathrm{c}$

Doz.

IRIS IIING. Yellow mauve, strong grower, striking and handsome, height $2 \mathrm{ft}$. 3 for $\$ 1.00$

ISOLENE. Lilac-purple, most beautiful and yet unmatched, distinct, sweet scented. Height $21 / 2 \mathrm{ft}$. 3 for $\$ 1.25$

JACQUISIANA. S.-copper-crimson, F.-maroon, extra good, height $21 / 2 \mathrm{ft} .3$ for $\$ 1.00$

IENT A. WILIIAMSON, Lavender-violet, very large, luxuriant grower, $3 \frac{1}{2}$ ft. 3 for $\$ 1.25 \ldots . . . . .$. 


\section{GERMAN IRISES-Continued}

IOHENGRIN. Cattleya-mauve, large flowers, vigorous. 3 for $75 \mathrm{c}$

IORD OF JUNE. Lavender blue, exceedingly handsome, sweet scented, height $31 / 2 \mathrm{ft}$. 3 for $\$ 1.75$

IMAGNIFICA. Enormous sweetly scented blooms, S.-violet-blue, F.-reddish-violet; yellow beard. Distinct. Height 3 ft. 3 for $\$ 2.25$

MIIE. SCHW ARTz. Pale mauve, exceptionally large flower's, tallest. 3 for $\$ 1.75$

MONSIGNOR. S.-crimson dotted lavender, inner petals ivory, F.-crimson edged lavender. 3 for $75 \mathrm{c}$

MOTHER OF PEARI. Delightful soft lavender, branching stem, height $4 \mathrm{ft}$. 3 for $\$ 1.75$

MRS. AIAIN GRAT. Mauve and Scarlet, blooms second time in August, lovely mass effect, height $21 / 2 \mathrm{ft} .3$ for $\$ 1.00$

PAIIIDA DAIMATICA. Large pale blue, broad foliage, sweet scented, height $3 \frac{1}{2}$ ft. 3 for $90 \mathrm{c}$

PRINCESS BEATRICE. (True.) Silvery lavender hlooms, ideal shape, handsomest of all, height $3 \mathrm{ft}$ 3 for $\$ 1.25$

PRINCESS VICTORIA IOUISE. S.-pale yellow F.-rich violet, edged cream. 3 for $75 \mathrm{c}$

PROSPEI IAUGIER. S.-bronze, F.-crimson, much admired, height $2 \frac{1}{2}$ ft. 3 for $75 \mathrm{c}$

PROSPERO. S.-pale lavender, flushed yellow base, S.-reddish-purple, lightly shaded margin, orange beard, handsome. 3 for $\$ 1.75$

QUAKER IADX. Smoky lavender, falls deeper. Iuch admired. 3 for $75 \mathrm{c}$

QUEEN CATERINA. Pale lavender violet, white haft, olange heard, handsome, lasting quality. 3 for $\$ 1.25$

QUEEN OF MAY. S.-lilac, F.--rose, most charming of the pinks, handsome, height $23 / 4$ f. 3 for $\$ 1.00$

REIN NIXE. S.-white, F.-blue, distinct white edge, vigorous, good habit, free flowering, height $21 \% \mathrm{ft} .3$ for $75 \mathrm{c}$

SHERWIN WRIGHT. Golden yellow, vigorous grower. 3 for $\$ 1.00$ SOUV. de IMME. GAUDICHAU. Finest rich purple, fragrant, fine shape. 3 for $\$ 2.00$

SWEET IAVENDER. S.-lavender violet, F.-rosy lavender, rufled, six spikes. 3 for $\$ 1.75$

TROOST. S.-rosy-purple, F.-rose. Remarkable for its color, height 2 ft. 3 for $\$ 1.75$

\section{JAPANESE IRIS (Kaempferi)}

Plant two inches deep in moist acid soils with sunny exposure, during June, July and August.

\section{LATEST INTRODUCTIONS}

Alagoz-Dhl. True purple. Inner petals white tipped purple. Iarge flower.

Azure-Dbl. Immense flower, exquisitely wavy Maure blue with darker halo around the yellow blotch at base of petals.

Bokhara-Sgl. Phlox purple, yellow blotch in center edged blue. Wavy petals.

Chutsai-Sgl. Hortense violet veined white. Inner petals phlox purple.

Daghastan-Dbl. Rosy-red veined white.

Gold Bound-Dbl. Pure white, one of the best.

Kha Khan-Sgl. White suffused blue, purple stigmas. Extra fine and large.

Ia Favorite-Dbl. Large, fine white, freely veined blue, and a rich purple center.

Mt. Hood-Dbl. Light blue shaded darker. Bright orange center.

Pyramid-Dbl. Violet purple, veined white in center of each petal.

Repsime-Dbl. Blue veined white.

Yama Yama-Sgl. White overlaid blue. Center petals white and purple. Crinkled appearance.

Price, any of the above, 50c each, $\$ 5.00$ per dozen. 


\section{BURNETT'S \\ Strawberry Plants}

POT.GROWN

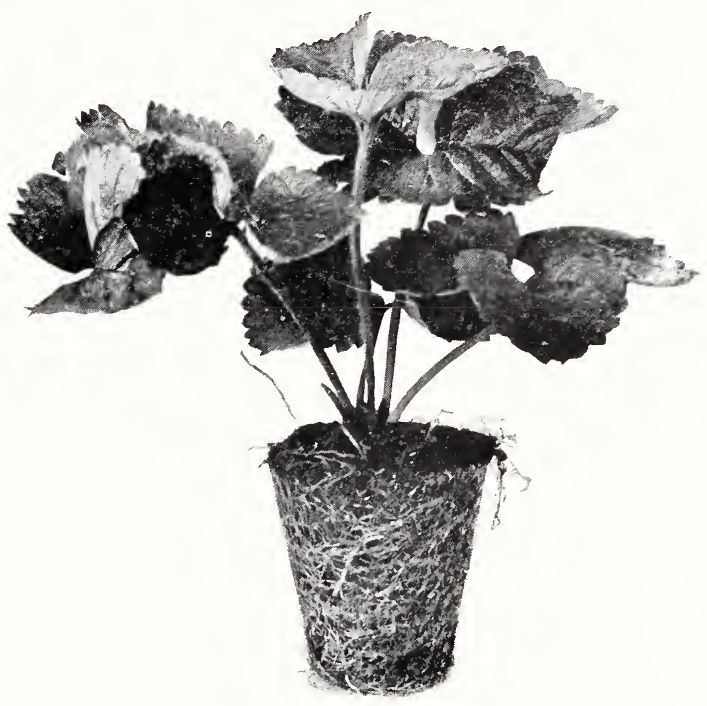

BARRYMORE. A fine midseason to late variety for growing where soil and climatic conditions are inclined to be cool. Its beautiful large firm berries are bluntly conical; of superb quality

BIG JOE. Late, ripening at the same time as the Chesapeake. Vely large and productive. In flavor it is one of the best; firm and a good shipper. succeeds upon almost all soils and under all conditions

BRANDYWINE. Berries are large, firm and solid, excellent in quality, with fine aromatic flavor. A vigorous grower. Midseason to late.

BUSHEX BASKET. Winner of the Barry Gold Medal. A giant in growth. Vigorous and healthy. It is enormously prolific and the fruit is of high qually. Mid-season

CHESAPEAKE. One of the best strawberries grown. It is very large, of fine form, as late as candy and in flavor ranks with "Marshall"

EARIY JERSEY GIANT. Extra early. Berries very large, scarlet-crimson color, has mild, wild strawberry flavor. Large and of vigorous growth

GANDY. The standard late variety by which all other late varieties are compared. A strong compact grower with large, firm berries of finest pact grower with large, firm berries of finest

GIEN MARY. A superb variety of large size, great productiveness and good quality.

MARSHAII. One of the richest flavored strawberries grown. Always the leader. Dark crimson when fully ripe, and of large size. Mid-season.

PREMIER. A grand early variety very productive. The berries are large, uniform in shape, of a glossy, rich red color, extending clear through the berry

ROYAI SOVEREIGN (True Stock). A splendid variety of English origin. Berries of large size, color rich crimson. Royal Sovereign is the king of all forcing strawberries 


\section{BURNETT'S \\ Strawberry Plants}

POT.GROWN

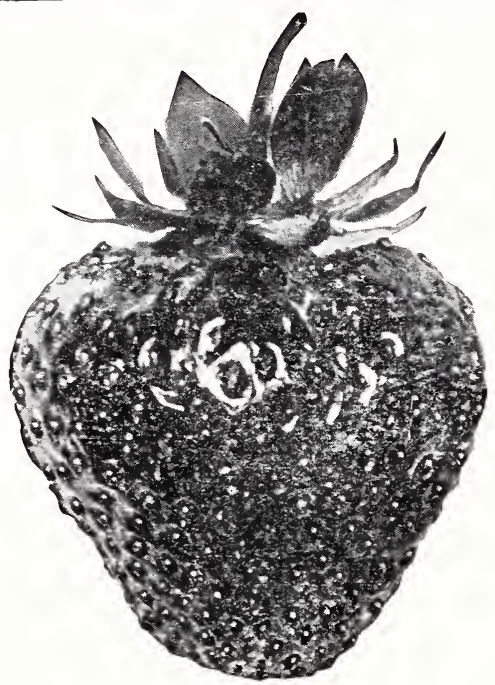

SHARPLESS, Berries are very large, irregular in shape and of good quality. One of the best for table use. Mid-season

STEVEN'S IATE CHAMPION. A grand variety, fruiting very late in the season, yielding large crops of fine berries

suCCEss. It is the best of the large, early varieties that we have fruited. The plant is exceptionally vigorous and prolific. Berries bright erimson

WIM. BEIT. Berries of large size and good quality; flesh solid, meaty, deep crimson in color. It begins to ripen quite early, continuing until almost the close of the season

NOTE: Varieties not mentioned in this list, we can supply at advertised prices.

\section{EVERBEARING STRAWBERRIES}

CHAMPION EVERBEARING. A seedling of Superb, and, like it in many respects, though it is more productive and the fruit is larger

MASTODON. This variety the past season produced more fruit and larger fruit than any other. It bears continuously from June until freezing weather, large, decidedly attractive berries, which are of simply superb flavor

PROGRESSIVE. One of the best fall-bearing sorts; strong grower; berries round, deep crimson. It begins to ripen with second earlies, bearing fruit until late fall

\section{BIRD NETTING}

For Protecting Strawberry Beds.

This we can supply in 20 and 30 -foot widths, 2 -inch mesh. (One lb. contains 200 square feet.) One $1 \mathrm{~b}$. of 20 -foot width will cover a bed of $20 \times 10$ feet. Three lbs. of 30 -foot width will cover a bed of $30 \times 20$ feet. $\mathbf{L}$ b. $\$ 3.00$.

\section{STRAWBERRY BASKETS}

1-Qt. Size, Square Shape, $100 \$ 1.75 ; 1000 \$ 16.00$ 2-Qt. Size, Oblong Shape, $1002.75 ; 100025.00$ 